energy thermal reactor), was used to study solutions of nuclear fuel in ordinary water.

\section{Atomic Energy}

A NUMBER of questions on the peaceful uses of nuclear energy were asked by Mr. R. Mason in an adjournment debate in the House of Commons on March 20. Replying for the Government, Sir Ian Horobin, Parliamentary Secretary to the Minister of Power, said that from his inquiries at Harwell the question of the drift of leading scientists to the United States does not appear to be a very urgent problem at present. The storage and disposal of nuclear waste is a great trouble but not so far a major difficulty, and the present system of allowing the early decay to proceed and concentrate has not faced the Authority with any insuperable difficulties. The direct conversion to electricity from ZETA is a long way ahead and not at the moment a practical consideration. We now know a great deal more about the Wigner release, so that categorical assurance could be given that such an accident as that at Windscale could not recur. Moreover, the tendency is towards the use of higher temperatures and consequently, with graphite-moderated reactors, greater annealing of the moderator. The prospects of finding uranium in the United Kingdom are extremely slight. As regards secrecy restrictions, there is every evidence that Britain has been free from considerable difficulties which have arisen elsewhere, and he thought our approach has been sensible and moderate and also that we have found happier and more practical arrangements for partnership between the Authority and industry than some other countries. Considerable progress is being made in connexion with conventional stations, and it is thought that the economic difficulties of air-cooling might be sufficiently offset by savings in fuel transport when the stations are located nearer to coal. For nuclear power stations, the enormous usage of water renders the chance of economic advantage very slight. Sir Ian firmly defended the declassification and publication arrangements made in regard to ZETA and claimed that the matter had been handled well by the Authority, which was entitled to the confidence of the House and of the nation.

\section{Human Sciences in Industry}

ANother stage in the development of psychology, sociology and related sciences in application to management, design and other industrial problems is marked by the decision of the Council for Scientific and Industrial Research to continue promoting research into the human problems of industry. In a written answer to a question in the House of Commons on January 21, Mr. H. Nicholls, the Parliamentary Secretary to the Ministry of Works, representing the Lord President of the Council, announced that the Council has set up a Committee on Human Sciences in Industry which will keep under review the development of the human sciences in relation to industrial needs, and will advise on the allocation of grants and on other means of promoting research in this field. On the side of the Department this Committee replaces the two former committees, on Human Relations in Industry and on Individual Efficiency in Industry, set up jointly with the Medical Research Council in 1953, agreement having been reached to replace them by separate committees reflecting the different interests of the two bodies.

A substantial flow of results is now coming from the research projects sponsored by those committees, on subjects ranging from psychological information theory applied to machine design to sociological aspects of technical change in the steel and other industries; the new Committee is expected to promote further applied research as well as more basic research in this field. Research and industrial interests are represented on the Committee, which has as chairman Mr. Lewis Wright (Amalgamated Weavers' Association), who is a member of the Council for Scientific and Industrial Research. The other members are Mr. P. W. S. Andrews (Nuffield College, Oxford); Mr. H. Briggs (Unilever, Ltd.); Prof. J. Drever (Edinburgh); Mr. E. Fletcher (Trades Union Congress); Prof. M. Gluckman (Manchester) ; Mr. H. G. Jones (Industrial Group, U.K. Atomic Energy Authority); Mr. H. G. Nelson (English Electric Company); Prof. E. A. G. Robinson (Cambridge) ; Miss B. N. Seear (London School of Economics) ; and Dr. A. T. M. Wilson (Tavistock Institute of Human Relations). The secretary is Mr. R. G. Stansfield.

\section{Supply of Teachers in Schools and Technical Colleges}

REPLYING for the Government in an adjournment debate on science teachers and National Service on March 17, Mr. R. Carr, Parliamentary Secretary to the Ministry of Labour and National Service, agreed most strongly with what Mr. W. Stones, Mr. E. Short and Dr. H. King had urged as to the importance of a sufficient number of adequately staffed technical colleges. Nevertheless he explained that, whereas technical colleges already have substantial help in their staffing problems from the existing arrangements for deferment, the even more favoured treatment of the secondary schools is a matter of deliberate policy, largely lecause of their greater need. In 1957 there were about 12,250 graduate teachers of mathematics and science in the schools and at least 300 unfilled vacancies. Between 1957 and 1964 the number of children more than fifteen years of age in the schools is expected to rise from about 250,000 to nearly 500,000 , and even if the present net annual increase of 500 in science and mathematics teachers is maintained, sixth-form classes in those subjects are likely to be overcrowded. This is the first reason why the Government is concerned to do nothing that might interrupt the flow of such teachers into secondary schools. The second reason is that it is considered desirable that teachers in a technical college should have had some industrial experience, and that accordingly any concession to benefit technical colleges should also be given to jobs requiring similar qualifications in industry. This was recognized by the Willis Jackson Committee ; the Government has moved a considerable way towards the more general and broader extension of deferment recommended by that Committee, but believes it is important to maintain a preference in favour of the schools. A third reason lies in the needs of the Services, which rely upon National Service to supply skilled scientific man-power until scientists can be recruited on a long-term basis. As regards the current position in the technical colleges, there was a net increase in full-time teachers of about 900 in 1956 ; for 1957 this was expected to be more than 1,000 ; and for 1958, about 1,400.

\section{Technical Teacher Training}

For the past ten years or so the technical teacher training colleges in Bolton, Huddersfield and London 